\title{
ENGLISH - SUNDANESE TRANSLATION
}

\section{ISTIKOMAH \& ADAM MUHAMMAD NUR}

Department of Linguistics, Postgraduate School, LPDP (Indonesia Endowment Fund for Education), Master in

Linguistics, Indonesia University of Education, Indonesia

\begin{tabular}{|l|}
\hline ABSTRACT \\
This study attempts to analyze personal deixis in the cross-cultural translation from English to Sundanese-one \\
of the local languages in Indonesia. In the process of translation, part of speech has been concerned as the alteration to \\
target language. Especially in Sundanese, this study focuses on the alteration and usage of personal deixis regarding to \\
the context of communication. The data are collected from the movie script titled Brick Mansion. The result of this study \\
shows that personal deixis of 'I' in the target language of Sundanese pointing some contexts and also this personal deixis \\
refers to the diction choice. The study reveals the high frequent personal deixis "I" in Sundanese, aing and urang, has \\
various collocations that describe strong language (curse words) and daily topic in communication. \\
KEYWORDS: Personal Deixis, Sundanese, Translation \& Pragmatics
\end{tabular}

Received: Jan 10, 2018; Accepted: Jan 30, 2018; Published: Feb 22, 2018; Paper Id.: IJELAPR20182

\section{INTRODUCTION}

The role of translation would have a big impact for vitality of language, mainly in case of local languages. In this study, researchers focus on translation of movie script from English to Sundanese, concentrating in personal deixis. The use of personal deixis "I" in target language (Sundanese) has various forms. These phenomena relate to understanding cultural relevance and context of communication form source language to target language. In analysing both spoken and written text, deixis or knowns as pointing - is one of tools in describing context appropriately. This study examines personal deixis in process of cross culture translation from English to Sundanese Language. As Grundy (2008) explains that lexical items encode context, this is called deictics[1]. He also describes types of deictics; personal deixis, time deixis, place deixis, spatial deixis.

In this study, researchers try to combine the translation method with corpus linguistics. The data are taken from movie script that are used as data corpus-driven. Based on Baker (2010) that corpus-driven method would be the inductive way in analysing data[2]. This study identifies the description of personal deixis used in target language (sundanese). Analysing data with corpus tools, Antconc, to get collocation of personal deixis "I". Anthony called this data corpora as a pararrel corpus, a corpus that contains source texts and their translations[3]. Some works about deixis have been examined in 2012 Yunanfathur Rahman - Universitas Gadjah Mada, has analysed German deixis[4]. He focused on the form of personal, place and time deixis. Another scholar, Rita Prasetiani (2004) - Universitas Indonesia, has classified the Arabic deixis into five deixis' [5]. She focused on the difference between personal and time deixis. More specific usage of deixis has been analysed by Henk[6] that described deictic categories as mitigating devices.

Based on those studies above, this study attempts to fill the gap in specific deixis, personal deixis in 
Translation English to Sundanese. Analyzing context regarding to the alteration of diction and their collocation with corpus linguistics method.

\section{REVIEW OF LITERATURE}

\section{Translation}

In knowing and understanding language to language is somehow complicated. The way people try to understand the different language around the world is by translating one language to another language. Translation is an activity that is delivering meaning from source language to target language. This study uses English and Sundanese as the object of translation. According to the process translation, Nida explains that:

First, the idea that translation is a science and second, the assumption

that translating depends on a theory of language that includes all

classes of texts, audiences, and circumstances of use. Translating is

not a separate science, but it often does represent specialized skills and

can also require aesthetic sensitivity. (Nida, 2006)[7]

Nida describes that what researchers do in translation is about delivering the idea and it needs sensitivity. The term sensitivity in this case relates to the cultural relevance according to the context of culture in target language. Nida also mentions about the aesthetic, this point indicates that translations need an acceptable manner of cultural context. In this study, translation has been done from English to Sundanese. Aspect of diction alteration concern with some description contexts

\section{Deixis}

Deixis is a discourse pointer. This function is to describe the concept or context in discourse. Grundy (2008) explains that in pointing discourse, there are some deixis; personal deixis, time deixis, spatial deixis, place deixis and social deixis.

Person deixis concerns the encoding of the participants in the speech

event in which the utterance in question is delivered. Place deixis

concerns the encoding of spatial locations relative to the locations of

the participants in the speech event. Time deixis concerns the

encoding of temporal points and spans relative to the time at which an

utterance was spoken (or a written message inscribed)

$$
\text { (Levinson, 1983)[8] }
$$

- First, person deixis, this term is focused in pronoun and participants in utterance. Pronoun in translation indicates various meaning and context.

- Second, place deixis, this relates to the place of speech events. This easily is understood as a location. 
- The last, time deixis, this relates to the adverb of time that points the context of utterance.

\section{Corpus Linguistics}

Mc Enery and Wilson through Baker (2006)[9] define that corpus linguistics is a study of language based on real usage. In addition, research in using corpus linguistics according to Vander Viana and friends (2011), has provided many useful indications, articularly at the lexical level[10]. This research uses one of corpus tools - collocation. Lexical level relates to the analysis of collocation in corpus. Examining corpus with main focus collocation has been analysed by Susi Yuliawati[11] that reveals representation from analysing collocation in sundanese magazine. The use of corpus method in this research is to help in analysing collocation of personal deixis in translation.

\section{Cohesion}

Information of the text can be easily understood by using cohesion. According to Carter and McCarty explains that :

Cohesion is the sense of semantic unity possessed by texts as opposed to random sequences of sentences; cohesion refer to the grammatical and lexical means by which written sentences and speakers' utterances are joined together to make texts. (Emilia, 2014)[12]

\section{Tenor}

Tenor belongs to register theory in Systemic Functional Linguistic study. Tenor refers to who is taking part, to the nature of the communicative participants, their status and roles: what kinds of role relationship obtain, including permanent and temporary relationships of one kind or another, both the types of speech roles they are taking on in the dialogue and the whole cluster of socially significant relationships in which they are involved (Halliday in Martin and White, 2005:29). Tenor refers to the role handled by the participants in a text (Halliday and Hasan, 1985)[13]. Tenor focuses on the semiotic relationship. Poynton in Eggins (2004:99) has suggested that it mediates these relationships along three dimensions, i.e. power or status, contact and affective involvement. Description more about tenor involves other cultural perspectives, such as social semiotics and sociolinguistics. Especially, in realization of tenor can be seen in the choice of grammatical areas.

Tabel 1: The Linguistic Consequences of Tenor

\begin{tabular}{|l|l|}
\hline \multicolumn{2}{|c|}{ The Linguistic Consequences of Tenor } \\
\hline \multicolumn{1}{|c|}{ Informal language } & \multicolumn{1}{c|}{ Formal language } \\
\hline Attitudinal lexis & neutral lexis \\
Colloquial lexis & formal lexis \\
-abbreviated forms & -full form \\
slang & -no slang (politeness phenomena) \\
Swearing & no swearing \\
Interruption & careful turn taking \\
First name & titles, no names \\
Nicknames & modalization to express deference \\
Modalization to express: & (must, oblige) \\
probability(might, possibly, probably, & modulation to express suggestion \\
may, usualy, always) & ( should) \\
Modulation to express opinion (reckon, & \\
think, guess sure) & \\
\hline
\end{tabular}




\section{Power}

Power explores the relationship of the interactants in social hierarchy culture. Power also refers to a position or distance between speaker and hearer. Status clarifies the interdependency level between the speaker and the hearer, the writer and the readers, and between the participants involved either equal or unequal. In conversation, power would be depicted in diction choice and this relates to analysis of personal deixis. Starting from mentioning someone's nickname and so on

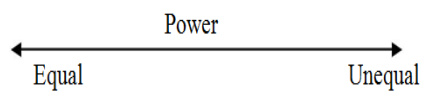

Figure 1: Power

\section{Contact}

Contact shows how often the interactant meet each other, however, contact somehow influences toward how the way the participants in the interaction are using language choice, especially in term of politeness or impoliteness and it represents the familiarity of language among the users, whether it is understandable or not.

$\underset{\text { Frequent }}{\stackrel{\text { Contact }}{\longrightarrow} \text { Occasional }}$

Figure 2: Contact

\section{Affective Involvement}

Affective involvement deals with the assesment or/and the assessment of the writer to the readers, the speaker to the hearer and the participants in term of discourse. This dimension refers to extent the emotional involvement in any situation. This aspect also refers to the politeness or impoliteness in communication between speaker and hearer.

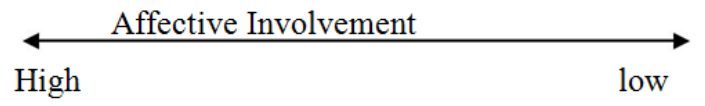

Figure 3: Affective Involvement

\section{DATA AND METHODS}

This study is a qualitative descriptive approach. However, there is a little aspect that uses a quantitative approach in analysing collocation. Data are taken from movie scripts of (Brick Mansion). Researchers collect 355 conversations from the script. Technically, data which are taken from the movie's script have been translated into Sundanese. After that, researchers use software AntConc to see collocation around the personal deixis "I" in target language.

Finally, researchers describe contexts and the descriptions of collocation results of personal deixis "I" in Sudanese. 


\section{RESULTS AND DISCUSSIONS}

Table 2: Collocation of Personal Deixis "I" in Sundanese

\begin{tabular}{|c|c|c|}
\hline \multicolumn{3}{|c|}{ Collocation of Personal Deixis 'I' in Sundanese } \\
\hline \multirow{3}{*}{ Aing } & $\begin{array}{l}\text { Nepi ka balad urang kadieu - - - Oke, } \\
\text { singkirkeun si kehed eta tina mobil aing! } \\
\text { Leuwih gancang! }\end{array}$ & $\begin{array}{l}\text { outside, you're all under arrest! Okay, get this } \\
\text { bastard off my car! Faster! }\end{array}$ \\
\hline & $\begin{array}{l}\text { naon nu ku maneh perbuat didieu? Kaluarkeun } \\
\text { aing ti dieu! Hei! Hei, kehed sia, kaluarkeun } \\
\text { aing! }\end{array}$ & $\begin{array}{l}\text { hell are you doing? } \\
\text { Get your hands off me! } \\
\text { Son of bitches! Let me out! }\end{array}$ \\
\hline & $\begin{array}{l}\text { Maneh teu nurutkeun anu diparentah ku aing, } \\
\text { goblog!!! awareh anak buah aing modar, }\end{array}$ & $\begin{array}{l}\text { Don't you go blame this on a woman, dawg. } \\
\text { There's five of my men down, }\end{array}$ \\
\hline \multirow{6}{*}{ Urang } & $\begin{array}{l}\text { jadikeun anu ka tujuh ? si Lino bogaeun } \\
\text { pamajikan.. - Arurang tewak we pamajikana }\end{array}$ & $\begin{array}{l}\text { make it seven? Hold up, hold up, Lino got a girl. } \\
\text { We grab that bitch }\end{array}$ \\
\hline & $\begin{array}{l}\text { Ulah waka balik sia lamun can meunang } \\
\text { pamajikan si Lino. Percaya ka urang, Lur } \\
\text { Oke. }\end{array}$ & $\begin{array}{l}\text { Don't come back } \\
\text { here without her. } \\
\text { Yo, trust me man. }\end{array}$ \\
\hline & $\begin{array}{l}\text { Manehna ek maehan urang duaan. Naon nu } \\
\text { kudu urang pigawe? Saha arurang? }\end{array}$ & $\begin{array}{l}\text { Tremaine's gonna slice y'all. } \\
\text { What do we do? } \\
\text { Who's we? }\end{array}$ \\
\hline & $\begin{array}{l}\text { Terus, aya Brick mansion. Perbatasan } \\
\text { sorangan... Urang sakola di sakolaan bisnis, } \\
\text { anu pangalusna di dunya. }\end{array}$ & $\begin{array}{l}\text { And then, we got Brick Mansions. } \\
\text { Our very own border... } \\
\text { I went to business school, the } \\
\text { best business school in the world. }\end{array}$ \\
\hline & $\begin{array}{l}\text { Arurang keur ngenalkeun jeung nu sejena. } \\
\text { Urang langsung wae kana bisnis Lola, Mangga } \\
\text { calik }\end{array}$ & $\begin{array}{l}\text { Me and home girl } \\
\text { gonna chill later. } \\
\text { Let me get down to business. } \\
\text { Lola, please. }\end{array}$ \\
\hline & $\begin{array}{l}\text { Urang pohokeun } 20 \mathrm{~kg} \text { eta. asal maneh daek } \\
\text { ngalepaskeun urang. Kumaha lamun urang } \\
\text { bisnis we? }\end{array}$ & $\begin{array}{l}\text { I forget about the } 20 \text { keys. } \\
\text { You go back with your } \\
\text { pretty girl in one piece. } \\
\text { And we stay of each other business. }\end{array}$ \\
\hline
\end{tabular}

Personal deixis of "I" in target language (sundanese) actually has several words, like abdi, aing, urang, and adi. These findings focus on the most frequent words of I - aing and urang.

\section{Personal Deixis of aing}

Analyzing word "an" in data movie script is 19 number of frequencies. This word collocates with informal languages that belong to strong language (curse words) like kehed, goblog. Interpretations would be analysed from tenor descriptions. Based on the collocation, these words- kehed; goblog- actually these words belong to position or power. Power is shown in the choice of words and referring to Systemic of Functional Linguistics known as communicative participant that commonly has equal position or power. These selected dictions also describe high affective involvement and this relation also refers to impoliteness in contact of communication.

\section{Personal Deixis of Urang}

The tendency of word "urang" is higher instead of using "aing". It has 64 number of frequency. Based on the table above, using the diction "urang" relates to the general topics, like pamajikan (women), bisnis (business) and pigawe (jobs). Social status and power in this diction describe unequal position. Affective involvement is low, based on the power relation, there is a distance or unequal position between speaker and hearer. Contact in communication tends to be polite. This contact is shown by the collocation words that mostly talks about general and formal topics and formal dictions. 


\section{CONCLUSIONS}

In Sundanese, context is really important to define before the speakers decide to produce utterances. Based on the result and discussion, analysing personal deixis "I" in target language from the movie script, has two frequent words that are aing and urang. Word "aing" refers to informal languages that belong to strong language context (curse words). On the other hand, word "urang" refers to formal languages that belong to a general topic discussion like women, business and jobs. In this research, the affective involvement has a correlation to contact of communication. Collocation words with high involvement tends to have contact as a impoliteness and vice versa. Suggestion for further research is to use data comparison of corpus-driven and do analysis with another aspect of pragmatics.

\section{ACKNOWLEDGMENTS}

We would like to give my appreciations for The Indonesia Endowment Fund for Education (LPDP RI), this research has been supported by LPDP RI. We would also like to sincerely thank the anonymous reviewers.

\section{REFERENCES}

1. Peter Grundy, Doing Pragmatics, Third Edit. London: Routledge, 2008.

2. P. Baker, "Sociolinguistics and Corpus Linguistics," Change, vol. 41, no. 1, p. 765, 2010.

3. Z. X. Anthony MCenery, "Parallel and Comparable Corpora: What are they up to?," RES-000-220135, 2010.

4. Y. Rahman, “Deixis in German Language,” Gadjah Mada University, 2012.

5. R. Prasetiani, “Deiksis Dalam Bahasa Arab,” Indonesia University, 2004.

6. H. Haverkate, “Deictic Categories As Mitigating Devices,” Pragmatics, pp. 505-522.

7. E. a. Nida, "Theories of Translation," Pliegos de Yuste, vol. 4, no. 1, 2016.

8. S. C. Levinson, Pragmatics. New York: Cambridge University Press, 1983.

9. P. Baker, Using Corpora in Discourse Analysis. London/New York: Continuum, 2006.

10. Sunita Agarwal, Re-Contextualizing Text: Translation and Discourse, International Journal of English and Literature (IJEL), Volume 5, Issue 5, September - October 2015, pp. 81-84

11. G. B. Vander Viana, Sonia Zyngier, Perspectives on Corpus Linguistics. Amsterdam/Philadelphia: John Benjamins Publishing Compay, 2011.

12. S. Yuliawati, “The Representation of Women In Sundanese Magazine Corpus (Mangle, 1958-2013): A Preliminary Study,” in 13th Association of Pacific Rim Universities (APRU), 2014, no. August.

13. E. Emilia, "Cohesion and Coherence," in Introducing Functional Grammar, Bandung: Dunia Pustaka Jaya, 2014, p. 92.

14. S. Eggins, An Introduction to Systemic Functional Linguistics, Second Edition. New York/London: Continuum, 2004. 